\title{
Targeted PI3K/AKT/mTOR therapy for metastatic carcinomas of the cervix: A phase I clinical experience
}

\author{
Ming-Mo Hou ${ }^{1,4}$, Xiaochun Liu ${ }^{1}$, Jennifer Wheler ${ }^{1}$, Aung Naing ${ }^{1}$, David Hong ${ }^{1}$, \\ Robert L. Coleman ${ }^{2}$, Apostolia Tsimberidou ${ }^{1}$, Filip Janku ${ }^{1}$, Ralph Zinner ${ }^{1}$, Karen Lu ${ }^{2}$, \\ Razelle Kurzrock ${ }^{3}$, Siqing Fu ${ }^{1}$ \\ ${ }^{1}$ Department of Investigational Cancer Therapeutics, The University of Texas MD Anderson Cancer Center, Houston, Texas \\ ${ }^{2}$ Department of Gynecologic Oncology, The University of Texas MD Anderson Cancer Center, Houston, Texas \\ ${ }^{3}$ UC San Diego Moores Cancer Center, La Jolla, California \\ ${ }^{4}$ Division of Hematology-Oncology, Chang Gung Memorial Hospital and Chang Gung University, Taoyuan, Taiwan \\ Correspondence to: \\ Siqing Fu, e-mail: siqingfu@mdanderson.org \\ Keywords: Cervical Cancer, Phase I Trial, Matched Therapy, PIK3CA mutation, PTEN loss \\ Received: July 21, $2014 \quad$ Accepted: October 09, 2014 Published: October 29, 2014
}

\section{ABSTRACT}

Background: Activated PI3K/AKT/mTOR pathway frequently occurs in metastatic or recurrent cervical carcinomas. However, the clinical benefits of matched therapy, a therapeutic approach targeting a specific mutational abnormality, have not yet been established.

Methods: We analyzed the outcomes of patients with metastatic or recurrent cervical carcinomas who had a test for PIK3CA mutation and/or PTEN loss/mutation, and received $\geq 1$ phase $I$ therapeutic regimen between January 2006 and June 2013.

Results: Patients with adenocarcinoma had fewer PIK3CA mutations (14\%), and survived longer (median, $\mathbf{1 4 . 2}$ months) than those with squamous cell carcinoma (48\% and 7.2 months; $p=0.016$, and 0.001 , respectively). Matched therapy targeting the activated PI3K/AKT/mTOR pathway led to a favorable rate of SD $\geq 6$ months/CR/ PR (53\%) and significantly longer progression-free survival (median, 6.0 months) than non-matched therapy ( $11 \%$ and 1.5 months; $p=0.08$ and 0.026 ; respectively). In patients with squamous cell carcinoma of the cervix, the presence of PIK3CA mutations was associated with a significantly longer overall survival (median, 9.4 months) than the absence of PIK3CA mutations (median, 4.2 months; $p=0.019$ ).

Conclusions: Matched therapy targeting the activated PI3K/AKT/mTOR pathway provided meaningful clinical benefits. Thus, further evaluation of PI3K/AKT/mTOR pathway targeted therapy is warranted, especially in metastatic or recurrent squamous cell carcinoma.

\section{INTRODUCTION}

Cancer of the uterine cervix is one of the most common gynecologic malignancies and causes of death worldwide [1]. In the United States, more than 12,000 women were diagnosed with cervical cancer in 2013, and more than 4,000 patients died from this disease [2]. Squamous cell carcinoma and adenocarcinoma account for about $95 \%$ of all cervical cancers [3]. Most patients who are diagnosed with early-stage disease have a high rate of long-term survival after they have undergone curative surgical resection and/or chemoradiotherapy $[4,5]$. Patients with recurrent or metastatic cervical cancers who are not amenable to radical local excision or curative chemoradiotherapy, have a poor prognosis [6, 7]. Palliative systemic therapies such as platinum-based doublets plus an anti-angiogenic agent as the standard of care for firstline treatment yield modest survival gains of 3.7 months [8-10]. Subsequent conventional chemotherapeutic regimens result in increased toxicity with limited clinical 
benefit [11]. The overall poor prognosis of these patients warrants the urgency for the development of novel therapeutic regimens $[12,13]$.

There are three classes of phosphoinositide 3-kinase (PI3K) isoforms [14]. Class I PI3Ks are heterodimeric lipid kinases composed of the p110 catalytic subunit and the p 85 regulatory subunit. Three major p110 isoforms have been described: p110 $\alpha$ (PIK3CA), p110 $\beta$ (PIK3CB), and p110 $(P I K 3 C D)[15,16]$. PI3K and PTEN counterpoise each other on conversion between phosphatidyl-inositol4-5-bisphosphate (PIP2) and phosphatidyl-inositol-3, 4, 5-trisphosphate (PIP3) $[17,18]$. Upon activation through either PIK3CA mutation or PTEN loss/mutation, PI3K phosphorylates PIP2 to PIP3, which facilitates recruitment and activation of AKT to initiate a cascade of downstream signaling events including the mTOR complex, a major downstream pathway [16]. Therefore, a regimen including a PI3K inhibitor and/or an mTOR inhibitor can be utilized to target PIK3CA mutation and/or PTEN loss/mutationmediated activated PI3K/AKT/mTOR pathway [19]. This strategy is defined as matched therapy: a therapeutic regimen including an agent (either as a single agent or as a part of a combination regimen) that is known to directly inhibit a specific mutation, and/or to inhibit its key downstream pathways, such as treatment with a PI3K inhibitor, an mTOR inhibitor, or these agent-based regimens for a cancer patient carrying a $P I K 3 C A$ mutation and/or PTEN loss/mutation [20].

Our previous study and others have documented that the activated PI3K/AKT/mTOR pathway is frequently identified in patients with metastatic or recurrent cervical cancers [21-25]. We hypothesized that cervix cancer patients with aberrations in this pathway would achieve clinical benefit (defined as objective response and prolonged stable disease) when treated with PI3K/AKT/ mTOR pathway targeted agents. In this article, we further our previous study by limiting patients who only have either squamous cell carcinoma or adenocarcinoma of the cervix in order to reach definitive conclusions, which will be applied to facilitate future drug development by choosing appropriate therapeutic regimens for appropriate cancer patients. Herein we document a clear observation of antitumor responses with acceptable toxicity from $\mathrm{PI} 3 \mathrm{~K} / \mathrm{AKT} / \mathrm{mTOR}$ matched therapy, representing an important new therapeutic strategy for a patient population possessing limited treatment options.

\section{PATIENTS AND METHODS}

\section{Patient selection}

Consecutive patients with metastatic or recurrent cervical carcinoma (either squamous cell carcinoma or adenocarcinoma) who were referred to the Department of Investigational Cancer Therapeutics (A Phase I Clinical Trials Program) at MD Anderson between January 1, 2006, and June 30, 2013, had a test for PIK3CA mutation and/or $P T E N$ loss/mutation in a Clinical Laboratory Improvement Amendments-certified molecular diagnostic laboratory, and received treatment in at least one phase I clinical trial, were evaluated. Follow-up was defined as the time of the initial office visit after the patient was referred to the phase I clinic until death or February 28, 2014. This study was conducted in accordance with MD Anderson's Institutional Review Board guidelines.

\section{Data collection}

Two individuals independently reviewed patients' electronic medical records at MD Anderson and crosschecked the collected data. Clinical information that was collected included race, prior treatment history (e.g., surgery, radiation therapy, and chemotherapy), date of birth, Eastern Cooperative Oncology Group performance status at the initial phase I clinic visit, mutation profiling of the tumor specimen including PIK3CA mutation and/or PTEN loss/mutation status, phase I clinical trial therapies, and clinical outcomes: severe adverse event (SAEs), progression-free survival (PFS), overall survival (OS), and objective responses including complete remission (CR), partial response (PR), and stable disease for 6 months or longer ( $\mathrm{SD} \geq 6$ months).

SAEs were defined as toxic effects that were grade 3 or higher according to the National Cancer Institute Common Terminology Criteria for Adverse Events v3.0 or v4.0 (http://ctep.cancer.gov/reporting/ctc.html) [26]. Clinical objective responses were evaluated according to the Response Evaluation Criteria in Solid Tumors version 1.0 or 1.1 per individual study protocols $[27,28]$. PFS was defined as the interval from the date of initial treatment to the first objective documentation of disease progression, the time of death if it occurred, or the last date of contact on February 28, 2014, at which time the patients' data were censored. OS was estimated from the date of the initial phase I clinical trial therapy to death or the last date of contact on February 28, 2014, at which time the patients' data were censored.

Enrollment of an eligible patient into a specific phase I trial depended on the availability of the phase I trial at the time of presentation and the preference of the treating physician according to good clinical practice. If a phase I trial was unsuccessful, another available phase I trial was introduced as long as a patient was eligible and willing to participate.

\section{Statistical analyses}

Categorical data were described using contingency tables. Continuously scaled measures were summarized with descriptive statistical measures (i.e., the median with the range), whereas PFS and OS rates were estimated using the Kaplan-Meier method. Patients who were 
still alive at the time of data analysis were censored at that time. Fisher's exact test was used to assess the associations between categorical variables and mutation status. Statistical inferences were based on two-sided tests at a significance level of $p<0.05$. Statistical analyses were carried out using SPSS Statistics version 22 (IBM Inc., Armonk, NY).

\section{RESULTS}

\section{Study population}

Fifty-five consecutive patients with metastatic or recurrent adenocarcinoma $(n=24)$ or squamous cell carcinoma $(\mathrm{n}=31)$ who had a test for PIK3CA mutation and/or PTEN loss/mutation and underwent treatment in at least one phase I clinical trial in the Phase I Clinical Trials Program were included in this study. Patient characteristics and molecular profiling are listed in Table 1. All patients had received at least one prior systemic chemotherapeutic regimen for metastatic or recurrent disease (median 2 regimens, range 1 to 4) and underwent molecular marker studies in a Clinical Laboratory Improvement Amendments-certified molecular diagnostic laboratory.

Twenty-two patients were found to harbor PIK3CA mutations and/or PTEN loss: $17(33 \%)$ of 51 tested patients with $P I K 3 C A$ aberrations $(\mathrm{E} 545 \mathrm{~K}=8, \mathrm{E} 542 \mathrm{~K}=4$, $\mathrm{H} 1047 \mathrm{~L}=1, \mathrm{H} 1047 \mathrm{R}=1, \mathrm{E} 545 \mathrm{~K}$ and $\mathrm{D} 549 \mathrm{H}=1$,

Table 1: Patient characteristics and molecular profiles.

\begin{tabular}{|c|c|c|c|}
\hline Patient characteristics & Adenocarcinoma & Squamous cell carcinoma & Total patients \\
\hline & $(n=24)$ & $(n=31)$ & $(\mathbf{n}=\mathbf{5 5})$ \\
\hline \multicolumn{4}{|l|}{ Age, years } \\
\hline Median (range) & $51(27-67)$ & $42(25-69)$ & $46(25-69)$ \\
\hline \multicolumn{4}{|l|}{ Race } \\
\hline White & 17 & 19 & 36 \\
\hline African American & 2 & 5 & 7 \\
\hline Hispanic & 3 & 6 & 9 \\
\hline Others & 2 & 1 & 3 \\
\hline \multicolumn{4}{|l|}{ Prior therapies } \\
\hline Surgery & 15 & 12 & 27 \\
\hline Radiotherapy & 23 & 28 & 51 \\
\hline Chemotherapy & 24 & 31 & 55 \\
\hline Antiangiogenic & 3 & 6 & 9 \\
\hline Median regimen & 2 & 2 & 2 \\
\hline (range) & $(1-4)$ & $(1-4)$ & $(1-4)$ \\
\hline \multicolumn{4}{|c|}{ Eastern cooperative oncology group performance status } \\
\hline 0 & 8 & 7 & 15 \\
\hline 1 & 14 & 17 & 31 \\
\hline 2 & 2 & 7 & 9 \\
\hline Molecular profiles & \multicolumn{3}{|c|}{ Aberrant/tested (\%) } \\
\hline PIK3CA & $3 / 22(14)$ & $14 / 29(48)$ & $17 / 51(33)$ \\
\hline PTEN & $4 / 16(25)$ & $3 / 24(13)$ & $7 / 40(18)$ \\
\hline TP53 & $3 / 7(43)$ & $1 / 12(8)$ & $4 / 19(21)$ \\
\hline HER2 & $1 / 9(11)$ & $1 / 14(7)$ & $2 / 23(9)$ \\
\hline CKIT & $0 / 11(0)$ & $2 / 18(11)$ & $2 / 29(7)$ \\
\hline
\end{tabular}

(Continued) 


\begin{tabular}{llll|}
\hline Patient characteristics & Adenocarcinoma & Squamous cell carcinoma & Total patients \\
\hline & $(\mathbf{n}=\mathbf{2 4})$ & $\mathbf{( n = 3 1 )}$ & $\mathbf{( n = 5 5 )}$ \\
\hline CMET & $0 / 11(0)$ & $2 / 18(11)$ & $2 / 29(7)$ \\
\hline KRAS & $3 / 19(16)$ & $0 / 26(0)$ & $3 / 45(7)$ \\
\hline$A L K 1$ & $0 / 7(0)$ & $1 / 13(8)$ & $1 / 20(5)$ \\
\hline$E G F R$ & $1 / 16(6)$ & $0 / 22(0)$ & $1 / 38(3)$ \\
\hline$B R A F$ & $0 / 18(0)$ & $0 / 25(0)$ & $0 / 43(0)$ \\
\hline$N R A S$ & $0 / 13(0)$ & $0 / 18(0)$ & $0 / 31(0)$ \\
\hline$A K T 1$ & $0 / 8(0)$ & $0 / 14(0)$ & $0 / 22(0)$ \\
\hline
\end{tabular}

E542K and M1043I $=1$, amplification $=1) ; 7(18 \%)$ of 40 tested patients with PTEN loss $(n=6)$ and/or mutation $(\mathrm{R} 173 \mathrm{C}=1)$; and 2 patients have both of PIK3CA mutation (E545K) and PTEN loss. Further analyses revealed that patients with squamous cell carcinomas were significantly younger and more likely to carry PIK3CA mutations than those with adenocarcinomas $(p=0.034$ per independent samples t-test for age and $\mathrm{p}=0.016$ per Fisher's exact test for PIK3CA mutations, respectively). Approximately $20 \%(\mathrm{n}=11 / 55)$ and $36 \%(\mathrm{n}=4 / 11)$ of the referred patients received subsequent second- and thirdline phase I trial therapies.

\section{Severe adverse events}

All patients were included for analyses of SAEs; a total of 450 cycles of therapy were administered according to 38 phase I clinical trials [21]. During their first phase I trial therapy, approximately $20 \%$ of patients $(n=11 / 55)$ experienced 19 episodes of SAEs: neutropenia and thrombocytopenia $(\mathrm{n}=5$ each, $9 \%)$; hyponatremia ( $\mathrm{n}=2,4 \%)$; and hypokalemia, hypomagnesaemia, hypophosphatemia, mucositis, fatigue, bowel perforation, and bacterial infection $(\mathrm{n}=1$ each, $2 \%)$. During the second phase I trial therapy, only $1(9 \%)$ of 11 patients had an SAE (fatigue). Subsequently, no patient experienced an SAE before all 4 patients progressed within the initial 8 weeks of their phase I trial therapy. In patients who received PI3K/AKT/mTOR pathway targeted therapeutic regimens, no apparent difference was observed between patients with PI3KCA mutation and/or PTEN loss/ mutation and those without.

\section{Antitumor activity}

The waterfall plot shown in Figure 1 demonstrates the best tumor response to their first-line phase I clinical trial therapy. Of 55 patients who received their firstline phase I trial therapy (see Tables 2 and 3), 35\% achieved $\mathrm{SD} \geq 6$ months $/ \mathrm{CR} / \mathrm{PR}(\mathrm{CR}=2, \mathrm{PR}=8$, and $\mathrm{SD} \geq 6$ months $=9$ ), and the median PFS in this group was 3.6 months $(95 \%$ confidence interval $[\mathrm{CI}], 2.3-5$; Figure 2A). Of 15 patients with PIK3CA mutations and/ or PTEN loss/mutations who received matched therapy, $53 \%$ achieved $\mathrm{SD} \geq 6$ months/CR/PR $(\mathrm{CR}=1, \mathrm{PR}=5$ and $\mathrm{SD} \geq 6$ months $=2$ ), and the median PFS in this group was 6.0 months (95\% CI, 3.2-8.8). These results compared favorably with nine patients who did not receive matched therapy targeting activated PI3K/AKT/mTOR pathway: $11.1 \%$ achieved PR (PR $=1 ; p=0.08)$, and the median PFS in this group was 1.5 months $(95 \%$ CI, $1.2-$ $1.8 ; p=0.026$; Figure 3A); as well as with seven patients without PIK3CA mutation and PTEN loss/mutations who received therapies targeting activated PI3K/AKT/ mTOR pathway: $14 \%$ achieved $\mathrm{PR}(\mathrm{PR}=1, p=0.16)$ and the median PFS in this group was 1.5 months $(95 \% \mathrm{CI}$, $0.4-10.6 ; p=0.06$ ).

Of 11 patients who received their second phase I clinical trial therapy, 27\% achieved $\mathrm{SD} \geq 6$ months/CR/ $\mathrm{PR}(\mathrm{PR}=1$ and $\mathrm{SD} \geq 6$ months $=2)$, and the median PFS in this group was 4.2 months (95\% CI, 3.0-5.4). Of 4 patients who received their third phase I clinical trial therapy, no patient achieved $\mathrm{SD} \geq 6$ months/CR/PR.

\section{Overall survivals}

All patients were included in survival analyses. The median OS was 9.1 months (95\% CI, 7.1-11.1 months; Figure 2A). Patients with metastatic or recurrent adenocarcinomas had a significantly greater median OS of 14.2 months (95\% CI, 7.8-20.6) than those with squamous cell carcinomas ( $\mathrm{OS}=7.2$ months; $95 \% \mathrm{CI}$, 5.3-9.1; $p=0.001$ ), as shown in Figure 2B. Patients with PIK3CA mutation and/or PTEN loss/mutation who received matched therapy, achieved a median OS of 10.1 months (95\% CI, 5.9-14.3), compared with those who did not (7.7 months; 95\% CI, 1.6-13.8; $p=0.43$; Figure 3B). Furthermore, patients with metastatic or 


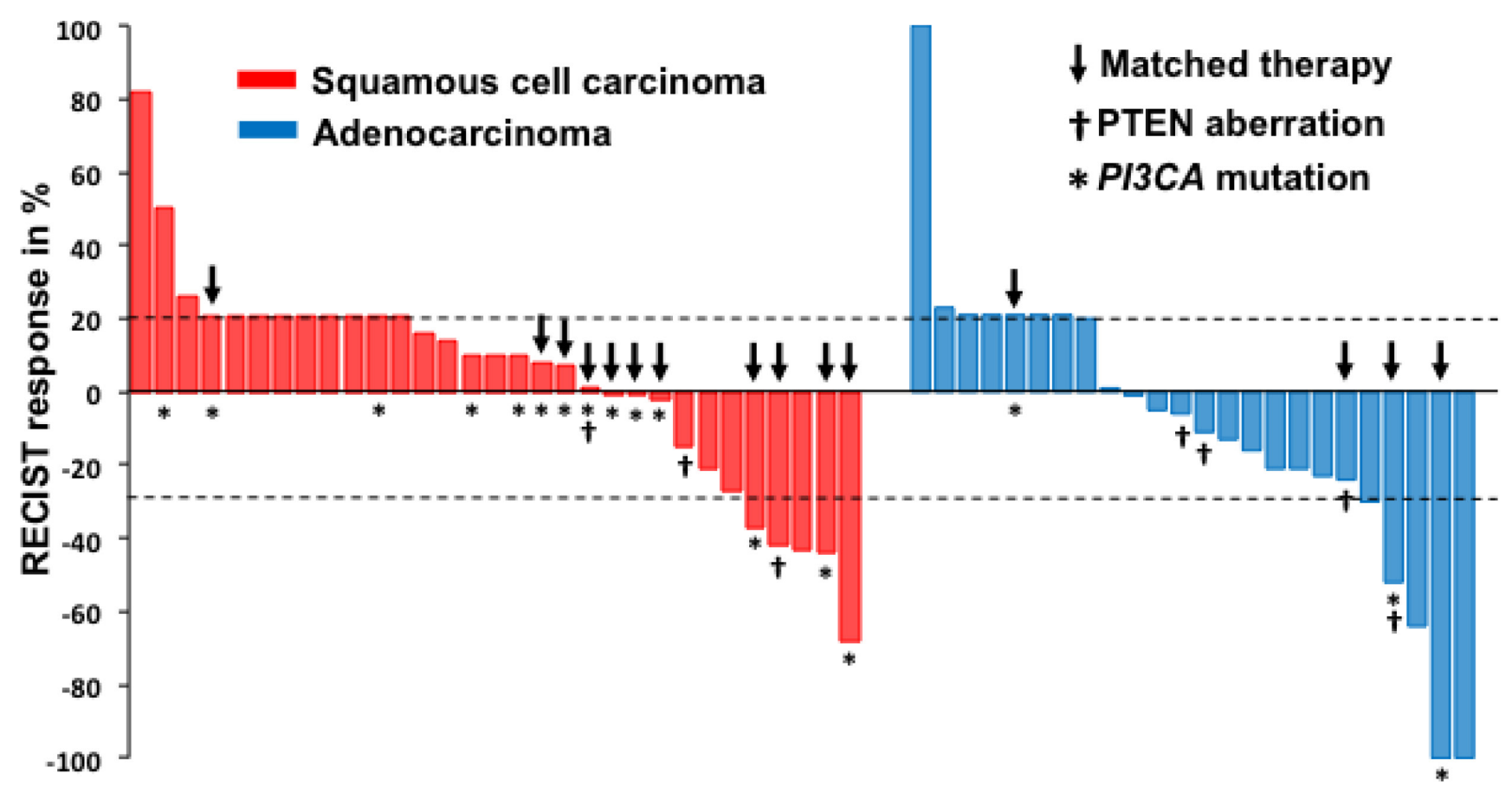

Figure 1: The waterfall plot shows the best tumor response to their initial phase I clinical trial therapy $(\mathrm{n}=55)$.

Table 2: Clinical outcomes in patients with advanced squamous cell carcinoma of the cervix.

\begin{tabular}{|c|c|c|c|c|c|c|c|}
\hline Age & PIK3CA mutation & $\begin{array}{l}\text { PTEN loss } \\
\text { or mutation }\end{array}$ & $\begin{array}{l}\text { Best tumor } \\
\text { response }\end{array}$ & $\begin{array}{l}\text { PFS } \\
\text { (months) }\end{array}$ & $\begin{array}{l}\text { OS } \\
\text { (months) }\end{array}$ & $\begin{array}{l}\text { Matched } \\
\text { therapy }\end{array}$ & Treatment \\
\hline 35 & E542K & ND & $-44 \%$ & 9.7 & 10.1 & Y & $\begin{array}{l}\text { Bevacizumab and } \\
\text { Temsirolimus plus Doxil }\end{array}$ \\
\hline 37 & E542K & $\mathrm{N}$ & $-37 \%$ & 10.3 & 10.3 & Y & A PI3K Inhibitor \\
\hline 37 & E542K & $\mathrm{N}$ & $-2 \%$ & 4.2 & 6.4 & $\mathrm{Y}$ & Everolimus and Pazopanib \\
\hline 42 & E542K & $\mathrm{N}$ & $21 \%$ & 0.9 & 2.5 & $\mathrm{~N}$ & Erlotinib and Praletrexate \\
\hline 59 & E542K / M1043I & $\mathrm{N}$ & $50 \%$ & 1.7 & 7.8 & $\mathrm{~N}$ & Erlotinib and Praletrexate \\
\hline 35 & E545K & Y & $0 \%$ & 4.4 & 10.8 & Y & $\begin{array}{l}\text { Bevacizumab and } \\
\text { Temsirolimus plus Doxil }\end{array}$ \\
\hline 56 & E545K & $\mathrm{P}$ & $8 \%$ & 6.4 & 13.6 & Y & Sirolimus and Docetaxol \\
\hline 48 & E545K & ND & $-68 \%$ & 32.6 & 40.3 & Y & $\begin{array}{l}\text { Bevacizumab and } \\
\text { Temsirolimus }\end{array}$ \\
\hline 40 & E545K & ND & $7 \%$ & 1.2 & 4.1 & Y & $\begin{array}{l}\text { Bevacizumab and } \\
\text { Temsirolimus plus Doxil }\end{array}$ \\
\hline 38 & E545K & $\mathrm{N}$ & $-1 \%$ & 6.7 & 7.0 & Y & $\begin{array}{l}\text { Bevacizumab and } \\
\text { Temsirolimus plus Doxil }\end{array}$ \\
\hline 46 & E545K & $\mathrm{N}$ & $10 \%$ & 5.4 & 9.3 & $\mathrm{~N}$ & $\begin{array}{l}\text { Lenalidomide and } \\
\text { Bevacizumab }\end{array}$ \\
\hline 48 & E545K & $\mathrm{N}$ & $10 \%$ & 3.5 & 9.4 & $\mathrm{~N}$ & $\begin{array}{l}\text { HAI Abraxane and } \\
\text { IV Gemcitabine plus } \\
\text { Bevacizumab }\end{array}$ \\
\hline 62 & E545K / D549H & ND & $21 \%$ & 0.7 & 2.1 & Y & $\begin{array}{l}\text { Bevacizumab and } \\
\text { Temsirolimus plus Doxil }\end{array}$ \\
\hline
\end{tabular}

(Continued) 


\begin{tabular}{|c|c|c|c|c|c|c|c|}
\hline Age & PIK3CA mutation & $\begin{array}{l}\text { PTEN loss } \\
\text { or mutation }\end{array}$ & $\begin{array}{l}\text { Best tumor } \\
\text { response }\end{array}$ & $\begin{array}{l}\text { PFS } \\
\text { (months) }\end{array}$ & $\begin{array}{l}\text { OS } \\
\text { (months) }\end{array}$ & $\begin{array}{l}\text { Matched } \\
\text { therapy }\end{array}$ & Treatment \\
\hline 61 & H1047R & $\mathrm{N}$ & $21 \%$ & 1.3 & 1.3 & $\mathrm{Y}$ & A PI3K Inhibitor \\
\hline 28 & $\mathrm{~N}$ & Y & $-42 \%$ & 6.0 & 6.0 & $\mathrm{Y}$ & $\begin{array}{l}\text { Bevacizumab and } \\
\text { Temsirolimus plus Doxil }\end{array}$ \\
\hline 49 & $\mathrm{~N}$ & $\mathrm{Y}$ & $-15 \%$ & 2.6 & 3.5 & $\mathrm{~N}$ & $\begin{array}{l}\text { Bendamustine and } \\
\text { Bevacizumab }\end{array}$ \\
\hline 62 & $\mathrm{~N}$ & $\mathrm{P}$ & $21 \%$ & 2.4 & 2.5 & $\mathrm{~N}$ & HAI Abraxane \\
\hline 36 & $\mathrm{~N}$ & $\mathrm{P}$ & $82 \%$ & 1.5 & 7.7 & $\mathrm{~N}$ & $\begin{array}{l}\text { Bevacizumab and } \\
\text { Temsirolimus plus Doxil }\end{array}$ \\
\hline 39 & $\mathrm{~N}$ & $\mathrm{P}$ & $21 \%$ & 1.1 & 1.3 & $\mathrm{~N}$ & $\begin{array}{l}\text { A MEK Inhibitor and } \\
\text { Docetaxol }\end{array}$ \\
\hline 41 & $\mathrm{~N}$ & $\mathrm{P}$ & $21 \%$ & 0.4 & 1.1 & $\mathrm{~N}$ & $\begin{array}{l}\text { Bevacizumab and } \\
\text { Temsirolimus plus } \\
\text { Carboplatin }\end{array}$ \\
\hline 34 & $\mathrm{~N}$ & ND & $-43 \%$ & 6.8 & 9.1 & $\mathrm{~N}$ & $\begin{array}{l}\text { Bevacizumab and } \\
\text { Temsirolimus }\end{array}$ \\
\hline 25 & $\mathrm{~N}$ & ND & $14 \%$ & 4.2 & 7.7 & $?$ & $\begin{array}{l}\text { A PI3K Inhibitor and } \\
\text { Carboplatin plus Paclitaxel }\end{array}$ \\
\hline 37 & $\mathrm{~N}$ & ND & $-27 \%$ & 1.4 & 10.9 & $?$ & $\begin{array}{l}\text { Bevacizumab and } \\
\text { Temsirolimus plus Doxil }\end{array}$ \\
\hline 43 & $\mathrm{~N}$ & $\mathrm{~N}$ & $10 \%$ & 7.9 & 12.4 & $\mathrm{~N}$ & Erlotinib and Praletrexate \\
\hline 58 & $\mathrm{~N}$ & $\mathrm{~N}$ & $16 \%$ & 4.1 & 4.6 & $\mathrm{~N}$ & Erlotinib and Praletrexate \\
\hline 29 & $\mathrm{~N}$ & $\mathrm{~N}$ & $21 \%$ & 2.7 & 4.2 & $\mathrm{~N}$ & $\begin{array}{l}\text { Bendamustine and } \\
\text { Bevacizumab }\end{array}$ \\
\hline 69 & $\mathrm{~N}$ & $\mathrm{~N}$ & $21 \%$ & 1.2 & 1.7 & $\mathrm{~N}$ & Erlotinib and Praletrexate \\
\hline 45 & $\mathrm{~N}$ & $\mathrm{~N}$ & $21 \%$ & 0.9 & 1.8 & $\mathrm{~N}$ & $\begin{array}{l}\text { HAI Oxaliplatin and PO } \\
\text { Capecitabine }\end{array}$ \\
\hline 63 & $\mathrm{~N}$ & $\mathrm{~N}$ & $21 \%$ & 0.5 & 0.7 & $\mathrm{~N}$ & Everolimus and Denosumab \\
\hline 48 & ND & $\mathrm{P}$ & $-21 \%$ & 6.9 & 12.4 & $?$ & $\begin{array}{l}\text { Bevacizumab and } \\
\text { Temsirolimus plus Doxil }\end{array}$ \\
\hline 37 & ND & $\mathrm{N}$ & $26 \%$ & 2.3 & 7.2 & $\mathrm{~N}$ & Trientine and Carboplatin \\
\hline
\end{tabular}

I, insufficient; N, no; ND, not done; OS, overall survival; P, partial loss; PFS, progression-free survival; Y, yes; +, censored; and ?, unknown.

recurrent squamous cell carcinomas who carried PIK3CA mutations $(\mathrm{n}=14)$ achieved a median OS of 9.4 months (95\% CI, 8.1-10.7), significantly longer than the median OS of those who did not carry PIK3CA mutations (n $=15 ; 4.2$ months, 95\% CI, 2.2-6.2; $p=0.019$ ), as shown in Figure 4A. Patients with metastatic or recurrent adenocarcinomas who carried PIK3CA mutations $(\mathrm{n}=3)$ achieved a median OS of 19.4 months (95\% CI, 0 - 43.6), similar to those who did not carry PIK3CA mutations ( $\mathrm{n}=19 ; 14.2$ months, 95\% CI, 4.0-24.4; $p=0.75$ ), as shown in Figure 4B. Patients with metastatic or recurrent $P T E N$-loss/mutation squamous cell carcinomas $(\mathrm{n}=3)$ and adenocarcinomas $(\mathrm{n}=4)$ achieved a median OS of
6 months $(95 \%$ CI, 2-10) and 11.3 months $(95 \%$ CI, 0-22.6), respectively, similar to the median OS of those with metastatic or recurrent $P T E N$-intact squamous cell carcinoma $(\mathrm{n}=21 ; 7$ months, $95 \% \mathrm{CI}, 3.1-10.9 ; p=0.76)$ and adenocarcinoma $(\mathrm{n}=16 ; 15.7$ months, $95 \% \mathrm{CI}$, 7.1-24.3; $p=0.79$ ), respectively (see Figure 5A and 5B).

\section{DISCUSSION}

In this study, we identified that patients with previously treated, locally advanced or metastatic cervical cancer harboring mutations in the PI3K/AKT/mTOR 
Table 3: Clinical outcomes in patients with advanced adenocarcinoma of the cervix.

\begin{tabular}{|c|c|c|c|c|c|c|c|}
\hline Age & $\begin{array}{l}\text { PIK3CA } \\
\text { mutation }\end{array}$ & $\begin{array}{l}\text { PTEN } \\
\text { loss or } \\
\text { mutation }\end{array}$ & $\begin{array}{l}\text { Best } \\
\text { tumor } \\
\text { response }\end{array}$ & $\begin{array}{l}\text { PFS } \\
\text { (months) }\end{array}$ & $\begin{array}{l}\text { OS } \\
\text { (months) }\end{array}$ & $\begin{array}{l}\text { Matched } \\
\text { therapy }\end{array}$ & Treatment \\
\hline 55 & Amplification & $\mathrm{P}$ & $-100 \%$ & $29.3+$ & $29.3+$ & Y & Everolimus and Anastrozole \\
\hline 61 & E545K & Y & $-52 \%$ & 18.7 & 19.4 & Y & $\begin{array}{l}\text { Bevacizumab and } \\
\text { Temsirolimus }\end{array}$ \\
\hline 51 & H1047L & $\mathrm{N}$ & $21 \%$ & 1.7 & 4.3 & Y & Sirolimus and Metformin \\
\hline 63 & $\mathrm{~N}$ & Y & $-24 \%$ & 1.7 & 7.9 & Y & $\begin{array}{l}\text { Bevacizumab and } \\
\text { Temsirolimus plus Doxil }\end{array}$ \\
\hline 41 & $\mathrm{~N}$ & $\mathrm{Y}$ & $-11 \%$ & $28.5+$ & $28.5+$ & $\mathrm{N}$ & An Aurora Kinase Inhibitor \\
\hline 50 & $\mathrm{~N}$ & $\mathrm{R} 173 \mathrm{C}$ & $-6 \%$ & 7.7 & 11.3 & $\mathrm{~N}$ & Pazopanib and Pemetrexate \\
\hline 44 & $\mathrm{~N}$ & $P$ & $-21 \%$ & 9.8 & 15.7 & $\mathrm{~N}$ & $\begin{array}{l}\text { A MEK Inhibitor and } \\
\text { Docetaxol }\end{array}$ \\
\hline 62 & $\mathrm{~N}$ & $\mathrm{P}$ & $20 \%$ & 2.1 & 19.7 & $\mathrm{~N}$ & A Proteasome Inhibitor \\
\hline 43 & $\mathrm{~N}$ & $\mathrm{P}$ & $-13 \%$ & $40.4+$ & $40.4+$ & $\mathrm{N}$ & A c-Met Inhibitor \\
\hline 51 & $\mathrm{~N}$ & ND & $-21 \%$ & 6.0 & 6.4 & $?$ & $\begin{array}{l}\text { Bevacizumab and } \\
\text { Temsirolimus }\end{array}$ \\
\hline 58 & $\mathrm{~N}$ & ND & $0 \%$ & 5.7 & 7.9 & $?$ & $\begin{array}{l}\text { Bevacizumab and } \\
\text { Temsirolimus plus Doxil }\end{array}$ \\
\hline 27 & $\mathrm{~N}$ & ND & $-29 \%$ & 3.7 & 21.7 & $?$ & $\begin{array}{l}\text { Bevacizumab and Cetuximab } \\
\text { plus Erlotinib }\end{array}$ \\
\hline 46 & $\mathrm{~N}$ & ND & $-16 \%$ & 2.9 & 3.5 & $?$ & $\begin{array}{l}\text { Bevacizumab and } \\
\text { Temsirolimus plus Doxil }\end{array}$ \\
\hline 58 & $\mathrm{~N}$ & ND & $430 \%$ & 2.5 & 20.8 & $?$ & $\begin{array}{l}\text { Temsirolimus and Topotecan } \\
\text { plus Bortezomib }\end{array}$ \\
\hline 63 & $\mathrm{~N}$ & ND & $21 \%$ & 2.1 & 2.4 & $\mathrm{~N}$ & Azacitidine and Oxaliplatin \\
\hline 44 & $\mathrm{~N}$ & $\mathrm{~N}$ & $-100 \%$ & 18.9 & $28.7+$ & $\mathrm{N}$ & $\begin{array}{l}\text { An Aurora Kinase Inhibitor } \\
\text { and Docetaxol }\end{array}$ \\
\hline 37 & $\mathrm{~N}$ & $\mathrm{~N}$ & $-64 \%$ & 10.6 & 35.6 & $\mathrm{~N}$ & $\begin{array}{l}\text { A PI3K Inhibitor and } \\
\text { Carboplatin plus Paclitaxel }\end{array}$ \\
\hline 59 & $\mathrm{~N}$ & $\mathrm{~N}$ & $0 \%$ & 3.7 & $5+$ & $\mathrm{N}$ & $\begin{array}{l}\text { Bevacizumab and VEGF } \\
\text { Inhibition }\end{array}$ \\
\hline 57 & $\mathrm{~N}$ & $\mathrm{~N}$ & $-23 \%$ & 3.2 & 14.2 & $\mathrm{~N}$ & $\begin{array}{l}\text { Bevacizumab and } \\
\text { Temsirolimus }\end{array}$ \\
\hline 49 & $\mathrm{~N}$ & $\mathrm{~N}$ & $-5 \%$ & 2.9 & 4.6 & $\mathrm{~N}$ & An Aurora Kinase Inhibitor \\
\hline 41 & $\mathrm{~N}$ & $\mathrm{~N}$ & $23 \%$ & 2.8 & 8.2 & $\mathrm{~N}$ & $\begin{array}{l}\text { Bevacizumab and } \\
\text { Temsirolimus plus Paclitaxel }\end{array}$ \\
\hline 60 & $\mathrm{~N}$ & $\mathrm{~N}$ & $21 \%$ & 0.7 & 2.1 & $\mathrm{~N}$ & $\begin{array}{l}\text { Bevacizumab and } \\
\text { Temsirolimus plus Sorafenib }\end{array}$ \\
\hline 67 & ND & I & $21 \%$ & 3.6 & $10.7+$ & $?$ & Everolimus and Anastrozole \\
\hline 40 & ND & I & $21 \%$ & 1.1 & 13.3 & $?$ & $\begin{array}{l}\text { Bevacizumab and } \\
\text { Temsirolimus plus Doxil }\end{array}$ \\
\hline
\end{tabular}

I, insufficient; N, no; ND, not done; OS, overall survival; P, partial loss; PFS, progression-free survival; Y, yes; +, censored; and ?, unknown. 

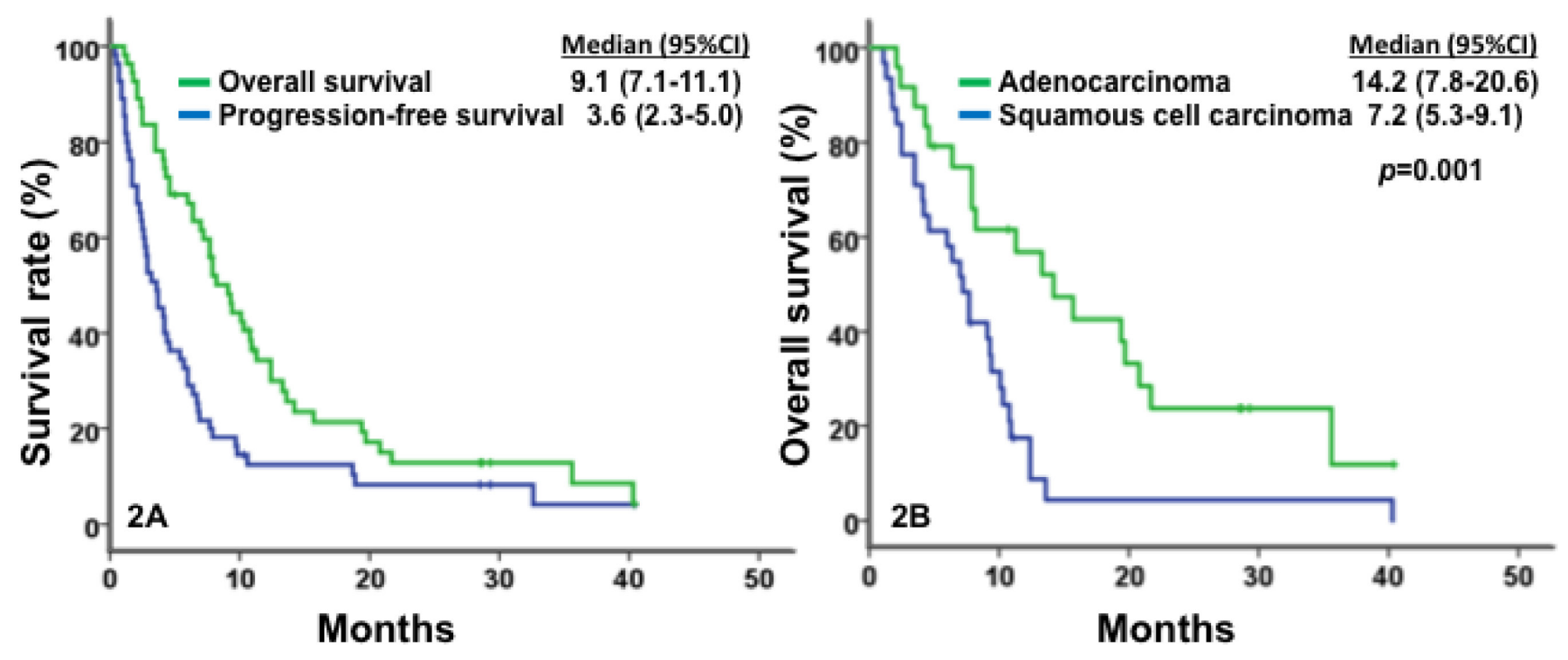

Figure 2: Kaplan-Meier plots for survivals. In Figure 2A, a median OS of 9.1 months (95\% CI, 7.1-11.1, in green) and a median PFS of 3.6 months $(95 \% \mathrm{CI}, 2.3-5.0$, in blue) were observed in patients with metastatic or recurrent cervical carcinomas $(\mathrm{n}=55)$. In Figure $2 \mathrm{~B}$, patients with adenocarcinoma (in green) showed a median OS of 14.2 months $(n=24 ; 95 \%$ CI, 7.8-20.6), significantly longer those with squamous cell carcinoma (in blue), 7.2 months ( $\mathrm{n}=31 ; 95 \% \mathrm{CI}, 5.3-9.1 ; p=0.001)$.
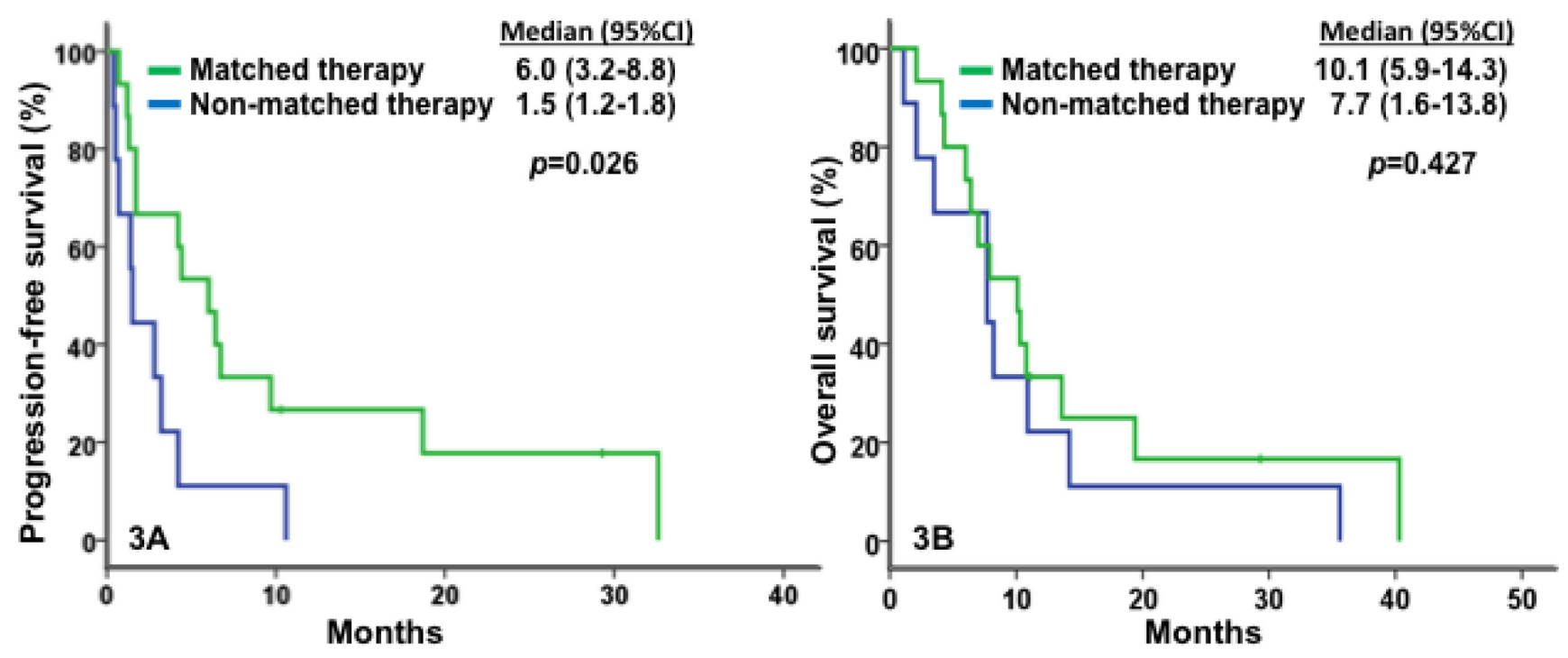

Figure 3: Kaplan-Meier plots for survivals. In Figure 3A, match therapy (in green) was associated with a median PFS of 6.0 months $(\mathrm{n}=15 ; 95 \% \mathrm{CI}, 3.2-8.8)$, significantly greater than non-matched therapy (in blue) with 1.5 months $(\mathrm{n}=9 ; 95 \% \mathrm{CI}, 1.2-1.8 ; p=0.026)$. In Figure 3B, matched therapy (in green) was associated with a median OS of 10.1 months ( $\mathrm{n}=15$; $95 \%$ CI, 5.9-14.3), compared to nonmatched therapy (in blue) with 7.7 months $(\mathrm{n}=9 ; 95 \% \mathrm{CI}, 1.6-13.8 ; p=0.427)$.

pathway achieved meaningful clinical benefit from a number of novel therapeutics administered in a phase I cancer center. Of particular interest were the objective responses, prolonged stable disease and PFS among these patients treated with PI3K/AKT/mTOR pathway targeted agents matching the somatic aberrations in this pathway. We conclude from these observations that targeted therapy among these patients with pathway potentiation is a viable strategy for further development.
Patients with metastatic or recurrent carcinoma of the cervix have limited therapeutic treatment options, particularly those in whom combination chemotherapy (without or with anti-angiogenesis agents) have been administered [11, 29, 30]. The Gynecologic Oncology Group (now NRG Oncology) developed phase II queues to explore chemotherapeutic (GOG 127 series, GOG 128 series) and biological agents (GOG 227 series) in this setting. Reflecting the poor anticipated outcomes in these 

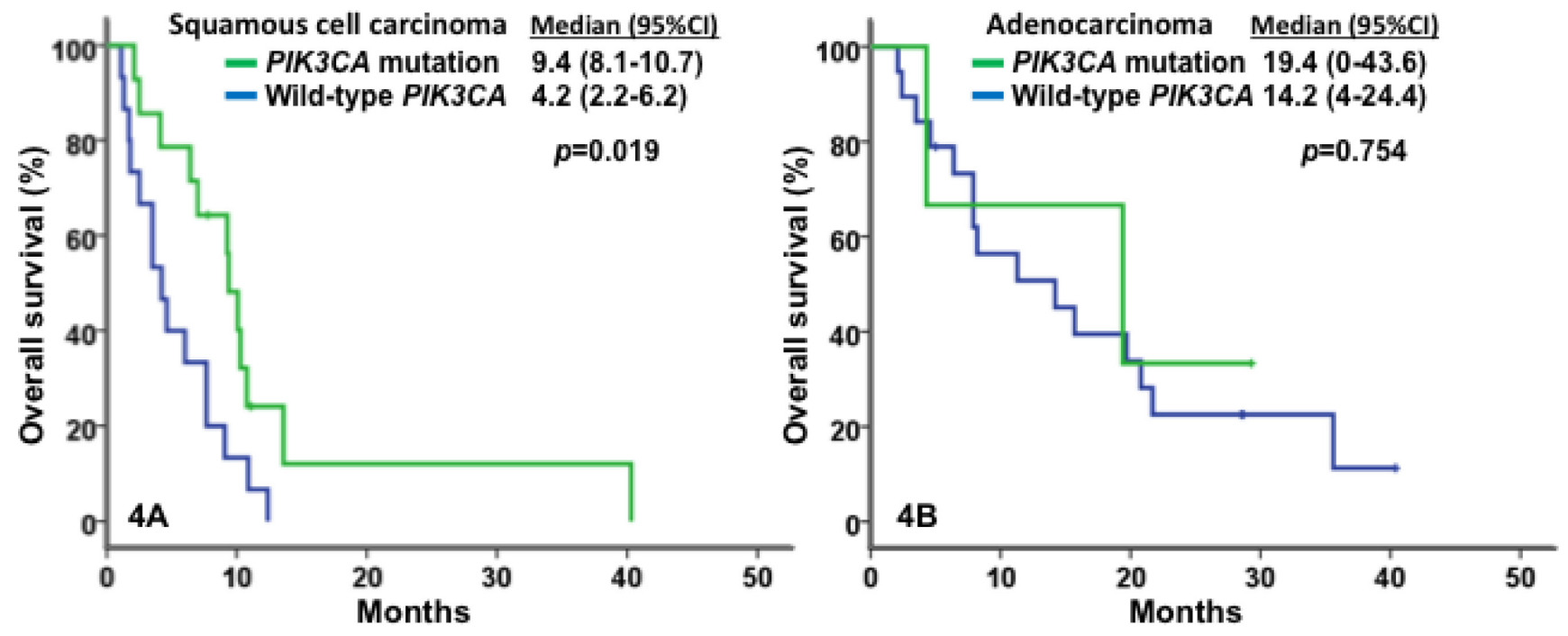

Figure 4: Kaplan-Meier plots for survivals. In Figure 4A for in patients with squamous cell carcinoma, $P I 3 K C A$ mutations (in green) were associated with a median OS of 9.4 months $(\mathrm{n}=14 ; 95 \% \mathrm{CI}, 8.1-10.7)$, significantly longer than wild-type $P I 3 K C A$ (in blue) with 4.2 months $(\mathrm{n}=15 ; 95 \% \mathrm{CI}, 2.2-6.2 ; p=0.019)$. In Figure $4 \mathrm{~B}$ for patients with adenocarcinoma, $P I 3 K C A$ mutations (in green) were associated with a median OS of 19.4 months $(\mathrm{n}=3 ; 95 \%$ CI, 0-43.6), compared to wild-type PI3KCA (in blue) with 14.2 months ( $\mathrm{n}=19$; $95 \%$ CI, 4-24.4; $p=0.754)$.
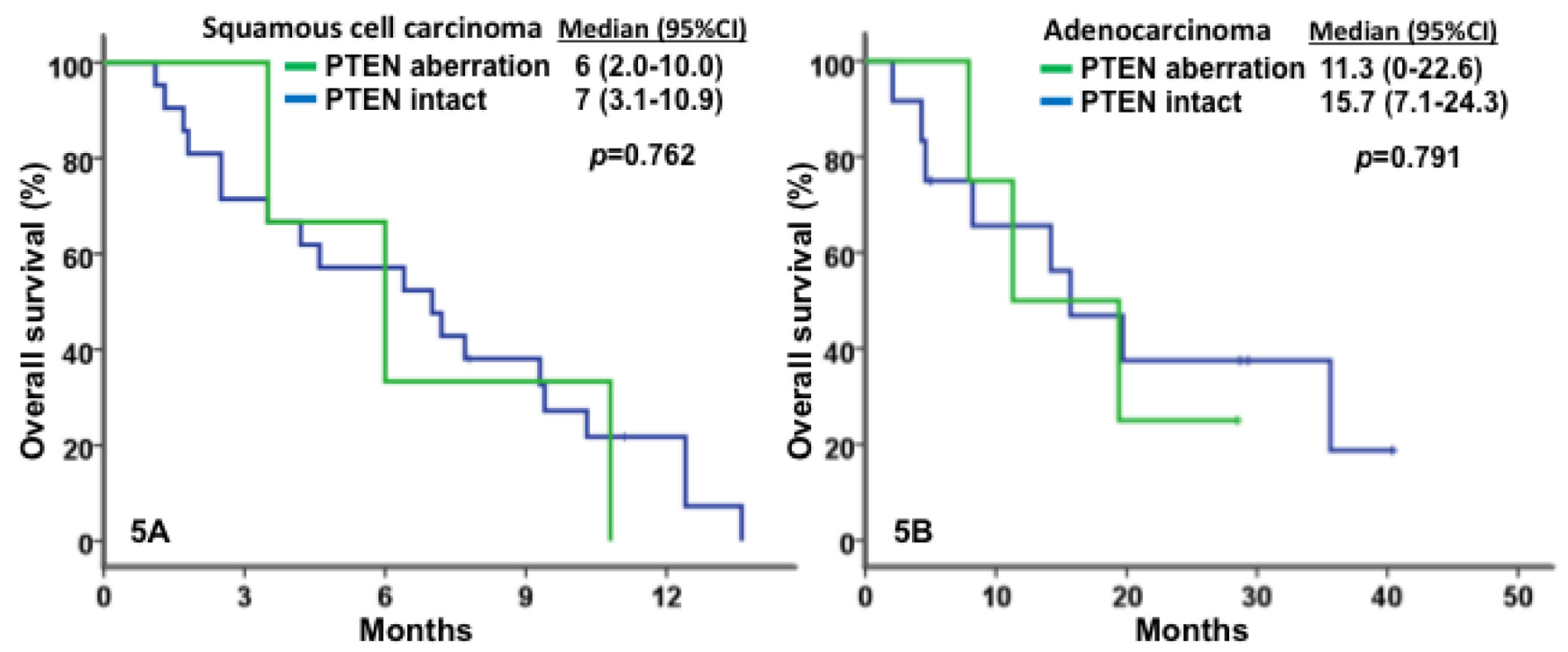

Figure 5: Kaplan-Meier plots for survivals. In Figure 5A for in patients with squamous cell carcinoma, PTEN aberrations (in green) were associated with a median OS of 6 months ( $\mathrm{n}=3 ; 95 \% \mathrm{CI}, 2-10)$, similar to PTEN intact (in blue) with 7 months ( $\mathrm{n}=21 ; 95 \%$ CI, $3.1-10.9 ; p=0.762$ ). In Figure 5B for patients with adenocarcinoma, PTEN aberrations (in green) were associated with a median OS of 11.3 months $(\mathrm{n}=4 ; 95 \%$ CI, 0-22.6), similar to PTEN intact (in blue) with 15.7 months ( $=16 ; 95 \%$ CI, 7.1-24.3; $p=0.791)$.

patient cohorts, the statistical decision rules were powered to evaluate "inactive" therapy at $\leq 15 \%$ for chemotherapy and $\leq 10 \%$ response and/or $\leq 10 \%$ non-progression at 6 months, respectively. This provides context upon which to examine the findings in this study.

Several observations are of note. In general, patients with metastatic or recurrent squamous cell carcinoma of the cervix were significantly younger, and had a higher prevalence of $P I K 3 C A$ mutations. However, they displayed lower antitumor activity to currently available phase I clinical trials at MD Anderson associated with significantly shorter OS than patients with metastatic or recurrent adenocarcinoma of the cervix. Second, matched therapy targeting the activated $\mathrm{PI} 3 \mathrm{~K} / \mathrm{AKT} / \mathrm{mTOR}$ pathway in patients with metastatic or recurrent squamous cell carcinoma of the cervix led to a favorably higher rate 
of $\mathrm{SD} \geq 6$ months/CR/PR as well as significantly longer PFS and OS than non-matched therapy. However, in patients with metastatic or recurrent adenocarcinoma of the cervix, there was no significant difference in OS associated with matched therapy in spite of a higher rate of $\mathrm{SD} \geq 6$ months/CR/PR and significantly longer PFS, which might be owing to at least three potential factors: lower prevalence of the activated PI3K/AKT/ mTOR pathway, intrinsic sensitivity to novel phase I trial therapy available at MD Anderson phase I service, and the presence of PIK3CA mutation and/or PTEN loss/ mutation that cannot stratify for aggressiveness of disease. Third, PIK3CA mutation, but not PTEN loss/mutation, was associated with significantly longer OS, indicating the differential effects of these genetic aberrations on sensitivity to matched therapy, as well as matched patients and the preferential choices of the treating physicians in the Phase I Clinical Trials Program, MD Anderson for assigning patients to matched therapy.

Of 136 patients with PIK3CA-mutation and/or $P T E N$-loss/mutation advanced solid tumors seen in our phase I clinic, $25 \%$ achieved $\mathrm{SD} \geq 6$ months/CR/PR (95\%CI, 0.18-0.33) after receiving matched therapy targeting the activated $\mathrm{PI} 3 \mathrm{~K} / \mathrm{AKT} / \mathrm{mTOR}$ pathway, and a median PFS of 2.5 months (95\% CI, 1.8-3.2) [31]. These outcomes were significantly lower than those reported in the current study of patients with $P I K 3 C A$ mutation and/or PTEN-loss/mutation metastatic or recurrent carcinoma receiving matched therapy. Several confounding factors might have contributed to these differences. Almost half of the patients with metastatic or recurrent cervical carcinoma, especially those with squamous cell carcinoma, presented with PIK3CA mutation and/or PTEN loss/mutation, and this proportion was significantly higher in patients with advanced solid tumors ( $48 \%$ versus $22 \%, p=0.002)$, suggesting that the activated $\mathrm{PI} 3 \mathrm{~K} / \mathrm{AKT} / \mathrm{mTOR}$ pathway is a driving mechanism for the survival of cervical carcinoma cells. Another factor is that concurrent mutations or specific molecular profiles might be more important than a single gene mutation. PIK3CA mutation was more prevalent in patients with $K R A S$ mutation than in patients with wildtype $K R A S$ [31], whereas in this report, a low frequency of $K R A S$ mutation was found in metastatic or recurrent cervical carcinomas, and in squamous cell carcinomas specifically, no KRAS mutation was identified in any of the 26 tested patients (Table 1). Since PIK3CA mutation and/ or PTEN loss/mutation with simultaneous KRAS mutation were associated with significantly lower antitumor activity and shorter PFS than PIK3CA mutation and/or PTEN loss/mutation without simultaneous KRAS mutation, two or more coexisting mutations constitute different classes of mutation profiles that predict responses to various biologically targeting agents and/or their combinations and render matched therapy more complicated than expected. When developing efficacious regimens to target the activated $\mathrm{PI} 3 \mathrm{~K} / \mathrm{AKT} / \mathrm{mTOR}$ pathway, metastatic or recurrent squamous cell carcinomas of the cervix might be an appropriate clinical model to be tested in early-phase clinical trials because of their high prevalence of PIK3CA mutation and/or PTEN loss/mutation as previously reported [15, 32-35] and their lack of simultaneous $K R A S$ mutation, in agreement with the hypothesis that coexisting $K R A S$ mutation become resistant to regimens targeting the activated $\mathrm{PI} 3 \mathrm{~K} / \mathrm{AKT} / \mathrm{mTOR}$ pathway.

When considering the clinical relevance of our findings, several limitations should be kept in mind. First, matched therapy includes not only phase I clinical trials of a single agent targeting the activated PI3K/ AKT/mTOR pathway, but also phase I clinical trials of an agent targeting this pathway in combination with other biologically targeted agents or conventional chemotherapeutic agents. The importance of using an agent to target the activated $\mathrm{PI} 3 \mathrm{~K} / \mathrm{AKT} / \mathrm{mTOR}$ pathway might be overestimated since tumor control might be induced by simultaneous inhibition of other key targets and/or processes by the combination regimens. Second, patients with poor clinical outcomes may have been selectively excluded from being referred to a phase I trial because of rapid tumor progression, poor performance status, insufficient organ function, severe comorbidity, economic issues, and inaccessibility of treatment. Third, molecular studies of mutation profiles were usually conducted on archival tumor specimens whenever available, regardless of whether the specimens had been treated in a phase I clinical trial. Finally, we had a limited sample size available for subgroup analyses, which confounded the ability to validate statistical significance in category assessment. Therefore, conclusions from this retrospective study should be considered preliminary evidence to generate hypotheses, which require further validation in larger prospective studies.

In conclusion, our results showed that almost half of the patients with metastatic or recurrent squamous cell carcinoma of the cervix had $P I K 3 C A$ mutation and/or $P T E N$ loss/mutation without coexisting KRAS mutation, providing an appropriate patient population to the test efficacy of a regimen including a single agent targeting the $\mathrm{PI} 3 \mathrm{~K} / \mathrm{AKT} / \mathrm{mTOR}$ pathway or a combination regimen with either another biologically targeted agent and/or conventional chemotherapeutic agent. Matched therapy targeting a specific mutation has provided apparent clinical benefits for cancer patients. Complicated mutation profiles might be more important and useful than a single gene mutation in predicting antitumor activity and clinical efficacy to a specific regimen [36-40]. Therefore, future development and evaluation of novel regimens targeting the activated $\mathrm{PI} 3 \mathrm{~K} / \mathrm{AKT} / \mathrm{mTOR}$ pathway for the purpose of translating high antitumor activity to prolonged survival benefit is warranted in larger prospective clinical trials for the treatment cervical carcinoma, especially squamous cell carcinoma. 


\section{ACKNOWLEDGEMENTS}

The authors thank Ellen Chiu in the Department of Investigational Cancer Therapeutics at MD Anderson for conducting database searches and Markeda Wade in the Department of Scientific Publications at MD Anderson for editing the manuscript.

\section{FUNDING}

RLC is supported by the Ann Rife Cox Chair in gynecology.

\section{Potential conflicts of interest}

The authors have no potential conflicts of interest to disclose.

\section{REFERENCES}

1. Forouzanfar MH, Foreman KJ, Delossantos AM, Lozano R, Lopez AD, Murray CJ, Naghavi M. Breast and cervical cancer in 187 countries between 1980 and 2010: a systematic analysis. Lancet. 2011; 378:1461-1484.

2. Siegel R, Ma J, Zou Z, Jemal A. Cancer statistics, 2014. CA: a cancer journal for clinicians. 2014; 64:9-29.

3. Grisaru D, Covens A, Chapman B, Shaw P, Colgan T, Murphy J, DePetrillo D, Lickrish G, Laframboise S, Rosen B. Does histology influence prognosis in patients with early-stage cervical carcinoma?. Cancer. 2001; 92:2999-3004.

4. Undurraga M, Loubeyre P, Dubuisson JB, Schneider D, Petignat P. Early-stage cervical cancer: is surgery better than radiotherapy? Expert Rev Anticancer Ther. 2010; $10: 451-460$

5. Reducing uncertainties about the effects of chemoradiotherapy for cervical cancer: a systematic review and metaanalysis of individual patient data from 18 randomized trials. J Clin Oncol. 2008; 26:5802-5812.

6. Long HJ 3rd, Bundy BN, Grendys EC, Jr., Benda JA, McMeekin DS, Sorosky J, Miller DS, Eaton LA, Fiorica JV. Randomized phase III trial of cisplatin with or without topotecan in carcinoma of the uterine cervix: a Gynecologic Oncology Group Study. J Clin Oncol. 2005; 23:4626-4633.

7. Monk BJ, Sill MW, McMeekin DS, Cohn DE, Ramondetta LM, Boardman $\mathrm{CH}$, Benda J, Cella D. Phase III trial of four cisplatin-containing doublet combinations in stage IVB, recurrent, or persistent cervical carcinoma: a Gynecologic Oncology Group study. J Clin Oncol. 2009; 27:4649-4655.

8. Barbera L, Thomas G. Management of early and locally advanced cervical cancer. Semin Oncol. 2009; 36:155-169.
9. Tewari KS, Monk BJ. Recent achievements and future developments in advanced and recurrent cervical cancer: trials of the Gynecologic Oncology Group. Semin Oncol. 2009; 36:170-180.

10. Tewari KS, Sill MW, Long HJ 3rd, Penson RT, Huang H, Ramondetta LM, Landrum LM, Oaknin A, Reid TJ, Leitao MM, Michael HE, Monk BJ. Improved survival with bevacizumab in advanced cervical cancer. N Engl J Med. 2014; 370:734-743.

11. Movva S, Rodriguez L, Arias-Pulido H, Verschraegen C. Novel chemotherapy approaches for cervical cancer. Cancer. 2009; 115:3166-3180.

12. Zagouri F, Sergentanis TN, Chrysikos D, Filipits M, Bartsch R. Molecularly targeted therapies in cervical cancer. A systematic review. Gynecol Oncol. 126:291-303.

13. Duenas-Gonzalez A, Cetina L, Coronel J, CervantesMadrid D. Emerging drugs for cervical cancer. Expert Opin Emerg Drugs. 17:203-218.

14. Wee S, Lengauer $\mathrm{C}$, Wiederschain D. Class IA phosphoinositide 3-kinase isoforms and human tumorigenesis: implications for cancer drug discovery and development. Current opinion in oncology. 2008; 20:77-82.

15. Ma YY, Wei SJ, Lin YC, Lung JC, Chang TC, Whang-Peng J, Liu JM, Yang DM, Yang WK, Shen CY. PIK3CA as an oncogene in cervical cancer. Oncogene. 2000; 19:2739-2744.

16. German S, Aslam HM, Saleem S, Raees A, Anum T, Alvi AA, Haseeb A. Carcinogenesis of PIK3CA. Hereditary cancer in clinical practice. 2013; 11:5.

17. Zhang S, Yu D. PI(3)king apart PTEN's role in cancer. Clinical cancer research : an official journal of the American Association for Cancer Research. 2010; 16:4325-4330.

18. Carnero A, Blanco-Aparicio C, Renner O, Link W, Leal JF. The PTEN/PI3K/AKT signalling pathway in cancer, therapeutic implications. Current cancer drug targets. 2008; $8: 187-198$

19. Kim KW, Myers CJ, Jung DK, Lu B. NVP-BEZ-235 enhances radiosensitization via blockade of the PI3K/ mTOR pathway in cisplatin-resistant non-small cell lung carcinoma. Genes \& cancer. 2014; 5:293-302.

20. Tsimberidou AM, Iskander NG, Hong DS, Wheler JJ, Falchook GS, Fu S, Piha-Paul S, Naing A, Janku F, Luthra R, Ye Y, Wen S, Berry D, Kurzrock R. Personalized medicine in a phase I clinical trials program: the MD Anderson Cancer Center initiative. Clin Cancer Res. 2012; 18:6373-6383.

21. Hou MM, Wheler J, Hong D, Naing A, Tsimberidou A, Janku F, Zinner R, Piha-Paul S, Falchook G, Kurzrock R, $\mathrm{Fu}$ S. Phase I Clinical Experience of Patients with Cervical Cancer. Anticancer Res. 2014.

22. Bertelsen BI, Steine SJ, Sandvei R, Molven A, Laerum OD. Molecular analysis of the PI3K-AKT pathway in uterine cervical neoplasia: frequent PIK3CA amplification and 
AKT phosphorylation. International journal of cancer Journal international du cancer. 2006; 118:1877-1883.

23. Cui B, Zheng B, Zhang X, Stendahl U, Andersson S, Wallin KL. Mutation of PIK3CA: possible risk factor for cervical carcinogenesis in older women. International journal of oncology. 2009; 34:409-416.

24. McIntyre JB, Wu JS, Craighead PS, Phan T, Kobel M, Lees-Miller SP, Ghatage P, Magliocco AM, Doll CM. PIK3CA mutational status and overall survival in patients with cervical cancer treated with radical chemoradiotherapy. Gynecologic oncology. 2013; 128:409-414.

25. Henken FE, Banerjee NS, Snijders PJ, Meijer CJ, De-Castro Arce J, Rosl F, Broker TR, Chow LT, Steenbergen RD. PIK3CA-mediated PI3-kinase signalling is essential for HPV-induced transformation in vitro. Molecular cancer. 2011; 10:71.

26. Cancer Therapy Evaluation Program NCI [16 April 2013];Common Terminology Criteria for Adverse events (CTCAE): http://ctep.cancer.gov/protocolDevelopment/ electronic_applications/ctc.htm.

27. Therasse P, Arbuck SG, Eisenhauer EA, Wanders J, Kaplan RS, Rubinstein L, Verweij J, Van Glabbeke M, van Oosterom AT, Christian MC, Gwyther SG. New guidelines to evaluate the response to treatment in solid tumors. European Organization for Research and Treatment of Cancer, National Cancer Institute of the United States, National Cancer Institute of Canada. J Natl Cancer Inst. 2000; 92:205-216.

28. Eisenhauer EA, Therasse P, Bogaerts J, Schwartz LH, Sargent D, Ford R, Dancey J, Arbuck S, Gwyther S, Mooney M, Rubinstein L, Shankar L, Dodd L, Kaplan R, Lacombe D, Verweij J. New response evaluation criteria in solid tumours: revised RECIST guideline (version 1.1). Eur J Cancer. 2009; 45:228-247.

29. Tao X, Hu W, Ramirez PT, Kavanagh JJ. Chemotherapy for recurrent and metastatic cervical cancer. Gynecol Oncol. 2008; 110:S67-71.

30. Hirte HW, Strychowsky JE, Oliver T, Fung-Kee-Fung M, Elit L, Oza AM. Chemotherapy for recurrent, metastatic, or persistent cervical cancer: a systematic review. Int J Gynecol Cancer. 2007; 17:1194-1204.

31. Janku F, Hong DS, Fu S, Piha-Paul SA, Naing A, Falchook GS, Tsimberidou AM, Stepanek VM, Moulder SL, Lee JJ, Luthra R, Zinner RG, Broaddus RR, Wheler JJ, Kurzrock R. Assessing PIK3CA and PTEN in early-phase trials with PI3K/AKT/mTOR inhibitors. Cell Rep. 2014; 6:377-387.

32. Lu D, Qian J, Yin X, Xiao Q, Wang C, Zeng Y. Expression of PTEN and survivin in cervical cancer: promising biological markers for early diagnosis and prognostic evaluation. Br J Biomed Sci. 2013; 69:143-146.

33. Bourmenskaya O, Shubina E, Trofimov D, Rebrikov D, Sabdulaeva E, Nepsha O, Bozhenko V, Rogovskaya S, Sukhikh G. Host gene expression profiling of cervical smear is eligible for cancer risk evaluation. J Clin Pathol. 2013; 66:282-285.

34. Vazquez-Ulloa E, Lizano M, Aviles-Salas A, Alfaro-Moreno E, Contreras-Paredes A. Abnormal distribution of $\mathrm{hDlg}$ and PTEN in premalignant lesions and invasive cervical cancer. Gynecol Oncol. 2011; 122:663-668.

35. Eijsink JJ, Noordhuis MG, ten Hoor KA, Kok M, Hollema H, de Bock GH, Nijman HW, Schuuring E, Wisman GB, van der Zee AG. The epidermal growth factor receptor pathway in relation to pelvic lymph node metastasis and survival in early-stage cervical cancer. Hum Pathol. 2010; 41:1735-1741.

36. McIntyre JB, Wu JS, Craighead PS, Phan T, Kobel M, Lees-Miller SP, Ghatage P, Magliocco AM, Doll CM. PIK3CA mutational status and overall survival in patients with cervical cancer treated with radical chemoradiotherapy. Gynecol Oncol. 2012; 128:409-414.

37. Janku F, Wheler JJ, Naing A, Falchook GS, Hong DS, Stepanek VM, Fu S, Piha-Paul SA, Lee JJ, Luthra R, Tsimberidou AM, Kurzrock R. PIK3CA mutation H1047R is associated with response to $\mathrm{PI} 3 \mathrm{~K} / \mathrm{AKT} / \mathrm{mTOR}$ signaling pathway inhibitors in early-phase clinical trials. Cancer Res. 2013; 73:276-284.

38. Janku F, Wheler JJ, Westin SN, Moulder SL, Naing A, Tsimberidou AM, Fu S, Falchook GS, Hong DS, Garrido-Laguna I, Luthra R, Lee JJ, Lu KH, Kurzrock R. $\mathrm{PI} 3 \mathrm{~K} / \mathrm{AKT} / \mathrm{mTOR}$ inhibitors in patients with breast and gynecologic malignancies harboring PIK3CA mutations. Journal of clinical oncology: official journal of the American Society of Clinical Oncology. 2012; 30:777-782.

39. Janku F, Tsimberidou AM, Garrido-Laguna I, Wang X, Luthra R, Hong DS, Naing A, Falchook GS, Moroney JW, Piha-Paul SA, Wheler JJ, Moulder SL, Fu S, Kurzrock R. PIK3CA mutations in patients with advanced cancers treated with $\mathrm{PI} 3 \mathrm{~K} / \mathrm{AKT} / \mathrm{mTOR}$ axis inhibitors. Molecular cancer therapeutics. 2011; 10:558-565.

40. Edgar KA, Crocker L, Cheng E, Wagle MC, Wongchenko M, Yan Y, Wilson TR, Dompe N, Neve RM, Belvin M, Sampath D, Friedman LS, Wallin JJ. Amphiregulin and PTEN evoke a multimodal mechanism of acquired resistance to PI3K inhibition. Genes \& cancer. 2014; 5:113-126. 